\title{
Netralitas Aparatur Sipil Negara Dalam Pemilihan Kepala Daerah Di Kabupaten Bener Meriah
}

\author{
Yandi Asda Mustika, Rasyidin, Suadi \\ Prodi Magister Administrasi Publik, Fakultas Ilmu Sosial dan Ilmu Politik Universitas Malikussaleh \\ Jln. Tengku Chik diTiro, NO. 26, Lancang Garam, Lhokseumawe-24351 \\ Korespondensi: e-mail: ras.ukm@gmail.com
}

\begin{abstract}
Penelitian ini mengkaji tentang implementasi undang-undang nomor 5 tahun 2014 tentang aparatur sipil negara dan mengkhususkan penelitian pada netralitas ASN dalam pemilihan kepala daerah di Kabupaten Bener Meriah pada tahun 2017. Tujuan Penelitian adalah untuk menganalisis penyebab yang menjadikan ASN tidak netral dan tindak lanjut punishment yang dilakukan oleh BKPP kepada ASN yang melakukan pelanggaran netralitas. Perspektif teoritik yang digunakan adalah teori implementasi kebijakan publik, netralitas birokrasi dan pilkada. Metode Penelitian yang digunakan adalah metode penelitian kualitatif. Hasil penelitian menunjukkan bahwa pada tahun 2017 dilakukan pemilihan kepala daerah di Kabupaten Bener Meriah, dan ditemukan 21 orang ASN meklakukan pelanggaran netralitas. Penyebab yang menyebabkan ASN melakukan pelanggaran netralitas dalam penelitian ini dianalisis menggunakan indikator implementasi menurut Van Horn dan Van Meter diketahui komunikasi dilakukan dengan memberikan sosialisasi penjabaran mengenai aturan-aturan netralitas ASN pada ranah politik, serta sanksi-sanksi yang akan diberikan jika para ASN melanggarnya. Indikator sumber daya tidak ditemukan kesesuaian dengan permasalahan penelitian. Watak para pelaksana kebijakan diketahui masih belum memiliki komtimen yang kuat dalam menjalankan amanah UU ASN karena dalam memberikan sanksi kepada 21 orang ASN yang melanggar netralitas hanya sekedar memberikan teguran lisan saja, SOP sampai saat ini hanya masih Undang-Undang Nomor 5 Tahun 2014 tentang Aparatur Sipil Negara dan Peraturan Pemerintah Nomor 53 Tahun 2010 tentang Disiplin Pegawai Negeri Sipil. Fragmentasi sebagai pelaksana adalahBKPP, Kesbangpol dan Panwaslih.Lingkungan ekonomi, sosial dan politik memberi pengaruh paling signifikan dalam permasalahan netralitas ASN karena faktor hubungan primordial dan faktor mengejar jabatan di pemerintahan. Tindakan punishment kepada para ASN hanya diberikan melalui teguran lisan dan masuk dalam kategori ringan, sementara pelanggaran yang dilakukan oleh ASN masuk dalam kategori sedang hingga berat.
\end{abstract}

Keywords: Netralitas, ASN, Pilkada

\section{Pendahuluan}

Aparatur Sipil Negara (ASN) sebagai abdi negara telah diatur batasan hubungannya dengan aktivitas-aktivitas politik praktis untuk memperkuat eksistensi dari netralitas ASN terhadap pelanggaran netralitas. Netralitas ASN merupakan bentuk nyata dari pemisahan hak politik dengan tugas dasar sebagai petugas di negara.

Pada konsep demokrasi, hak dasar dan hak asasi tidak bisa dilepaskan dari prinsip kebebasan. 
Secara umum netralitas ASN dipertanyakan karena ASN memiliki hak untuk ikut memilih dalam pesta demokrasi, namun disatu sisi lainnya tidak diperkenankan terlibat dalam berbagai macam aktivitas politik seperti terlibat dalam kampanye-kampanye politik, bahkan untuk memasang foto di media sosial dengan salah satu calon yang mengikuti pemilihan umum.

Pelanggaran netralitas dalam birokrasi dapat mempengaruhi kinerja para ASN, baik secara internal maupun eksternal lingkungan tempat mereka bekerja. Dalam menjalankan tugas, wewenang dan tanggung jawabnya sebagai aparatur negara dan pelayan publik, ASN penting untuk memiliki kebebasan dari pengaruh-pengaruh eksternal (seperti pengaruh dari partai politik tertentu). Ketiadaan pengaruh eksternal ini dimaksudkan agar ASN dapat menjalankan tugas dan tanggungjawabnya secara lebih demokratis sehingga hasil pelaksanaan pekerjaannya tidak menguntungkan salah satu pihak tertentu. Hal ini juga dimaksudkan untuk lebih memperjelas garis akuntabilitas ASN.

Terdapat 21 ASN yang melakukan pelanggaran netralitas pada Pilkada Tahun 2017 yang disebabkan oleh berbagai macam faktor. Atas dasar permasalahan tersebut peneliti tertarik untuk meneliti lebih lanjut tentang Netralitas Aparatur Sipil Negara Dalam Pemilihan Kepala Daerah Di Kabupaten Bener Meriah.

\section{Rumusan Masalah}

1. Apa sajakah penyebab yang menjadikan aparatur sipil negara tidak dapat menjaga netralitasnya dalam pemilihan kepala daerah di Kabupaten Bener Meriah?

Mengapa ASN yang melakukan pelanggaran netralitas dalam pemilihan kepala daerah tidak dilanjuti dengan pemberian punishment oleh BKPP Kabupaten Bener Meriah?

\section{Kajian Terdahulu: Landasan Teoritis}

Teori merupakan landasan yang teramat penting dalam memahami, menafsirkan dan memaknai data, oleh karena itu untuk memudahkan penafsiran data dalam penelitian ini, maka penulis menggunakan beberapa teori sebagai berikut:

\section{Kebijakan Publik}

Kebijakan publik adalah keputusan politik yang diterapkan oleh perangkat/pejabat pemerintah. Ciri khusus dari kebijakan publik adalah keputusan daripihak berwenang dalam sebuah sistem politik yang berlaku yaitu para senior, eksekutif, legislatif, kepala tertinggi daerah, hakim, administrator dan sebagainya (Agustino (2008: 8). Eyestone berpendapat bahwa orang-orang yang memiliki kewenangan pada sistem politik dalam mewujudkan kebijakan publik tersebut melibatkan orang-orang dalam sistem politik dan memiliki tanggung jawab dalam suatu urusan atau masalah.

\section{Implementasi Kebijakan}

Implementasi kebijakan publik (Public Policy Implementation) merupakan salah satu tahapan dari proses kebijakan publik. Implementasi kebijakan publik menurut Webster: "to 
provide the means for carrying out (menyediakan sarana untuk melakukan sesuatu); to give practical effect to" (menimbulkan dampak atau akibat terhadap sesuatu). Dari pengertian implementasi kebijakan menurut Webster ini dapat ditarik kesimpulan bahwa implementasi berarti menyediakan sarana untuk melaksanakan suatu kebijakan dan dapat memunculkan dampak akibat terhadap sesuatu tertentu.

Nugroho (2003:158) mengartikan implementasi/ penerapan kebijakan pada prinsipnya adalah cara agar sebuah aturan dapat mencapai target (tidak lebih dan tidak kurang). Selanjutnya Nugroho (2003:158) menyatakan perencanaan atau sebuah kebijakan yang baik akan mengahasilkan sesuatu yang baik. Konsep (yang didukung data dan informasi masa depan) kontribusinya mencapai proporsi sekitar $60 \%$ terhadap keberhasilan kebijakan tersebut dan proporsi sekitar $40 \%$ terhadap implementasi yang harus konsisten dengan konsep.

Dalam ruang lingkup kecil implementasi memilik pengertian yaitu pelaksanaan atau penerapan. Browne, Wildavsky dalam Usman (2004: 7) menyatakan implementasi/ penerapan adalah kegiatan memperluas aktivitas yang saling menyesuaikan. Syaukani (2004: 295) menyatakan implementasi merupakan rangkaian aktivitas memberikan peraturan kepada masyarakat untuk diterapkan bersama dan menghasilkan manfaat demi kepentingan bersama.

Rangkaian kegiatan tersebut meliputi peraturan-peraturan sebagai interpretasi dari kebijakan tersebut, menyiapkan sumber daya untuk melakukan penggerakkan terhadap suatu kegiatan pelaksanaan atau implementasi yang termasuk adanya sumber daya finansial, sarana prasarana serta penanggung jawab untuk kemudian memberikan kebijaksanaan kepada masyarakat secara nyata. Keberhasilan penerapan kebijakan dipengaruhi oleh indikator-indikator yang saling berhubungan.

Permasalahan penelitian akan dianalisis menggunakan teori implementasi menurut Van Horn dan Van Meter dengan indikator komunikasi, sumber daya, disposisi, struktur birokrasi, serta lingkungan ekonomi, sosial dan politik

\section{Aparatur Sipil Negara}

Pascadikeluarkannya Undang-Undang Nomor 5 Tahun 2014 Tentang Aparatur Sipil, sebutan pegawai pemerintah yang dahulunya PNS (Pegawai Negeri Sipil) berubah menjadi Aparatur Sipil Negara disingkat ASN. Sebelumnya, ketentuan mengenai pegawai pemerintah diatur dalam Undangundang Nomor 43 Tahun 1999 tentang Perubahan atas Undang-undang Nomor 8 Tahun 1974 tentang Pokok-Pokok Kepegawaian.

Dalam aturan ini disebutkan bahwa PNS merupakan salah satu sarana tata usaha negara yang diangkat dan digaji oleh pemerintah untuk melaksanakan tugas negara tertentu berdasarkan peraturan yang telah dibuat dan ditetapkan oleh negara. Pegawai Negeri Sipil sebagai abdi negara dan abdi masyarakat mempunyai tanggung jawab untuk melaksanakan tugasnya masing-masing. (Agustina. 2002: 32). 
Dalam menjalankan tugasnya, Aparatur Sipil Negara mempunyai kewajiban yang harus ditaati yaitu:

a. Wajib setia dan taat kepada Pancasila, Undang- Undang Dasar 1945, Negara dan Pemerintah, serta wajib menjaga persatuan dan kesatuan bangsa dalam Negara Kesatuan Republik Indonesia (Pasal 4).

b. Wajib menaati segala peraturan perundang-undangan yang berlaku dan melaksanakan tugas kedinasan yang dipercayakan kepadanya dengan penuh pengabdian, kesadaran dan tanggung jawab (Pasal 5).

c. Wajib menyimpan rahasia jabatan dan hanya dapat mengemukakan rahasia jabatan kepada dan atas perintah pejabat yang berwajib atas kuasa undang-undang (Pasal 6). (UU ASN).

\section{Netralitas Aparatur Sipil Negara}

Menurut Kamus Besar Bahasa Indonesia (KBBI), netralitas merupakan keadaan dan sikap netral, dalam arti tidak memihak atau bebas. Menurut Marbun dalam Sri Hartini (2014) bahwa netralitas adalah bebasnya pegawai negeri sipil dari pengaruh kepentingan seperti partai politik tertentu juga tidak memihak untuk kepentingan partai politik tertentu atau tidak berperan dalam proses politik. Netralitas ASN mengandung makna impartiality yang artinya adil, objektif, bebas pengaruh, bebas intervensi, tidak bias dan tidak berpihak pada siapapun.

Menurut Undang-Undang Nomor 5 Tahun 2014 tentang Aparatur Sipil Negara, ASN berfungsi sebagai pelaksana kebijakan publik, penyelenggara pelayanan publik dan perekat dan pemersatu bangsa. Untuk melaksanakan fungsi tersebut, ASN diberi kewenangan mengelola keuangan dan asset negara, menggunakan fasilitas negara serta membuat kebijakan yang berdampak pada masyarakat luas. Agar kewenangan tersebut tidak disalahgunakan dan hanya menguntungkan kelompok tertentu maka ASN harus bersikap netral. ASN tidak diperbolehkan menggunakan uang dan asset negara untuk kepentingan kelompok tertentu. ASN juga dilarang membuat kebijakan yang bersifat diskriminatif dan mengutamakan pelayanan hanya kepada kelompok tertentu saja.

Netralitas ASN sangat penting dalam menciptakan tata pemerintahan yang baik serta birokrasi yang berorientasi pada pelayanan publik. Sebagaimana dikatakan oleh Prof. Sofian Effendi: “ASN itu harus netral (impartial), tidak boleh berpihak dan tidak boleh memihak dalam melaksanakan tugas dan fungsinya”. Imparsialitas sebagai kesetaraan politik, yaitu perlakukan yang tidak memihak pada siapapun dalam melaksanakan wewenang publik berdasarkan undang-undang dan kebijakan tanpa mempertimbangkan hubungan khusus, referensi pribadi dan hal-hal lain di luar hukum (Robert Dahl, 1992).

Pandangan birokrasi harus netral dari pengaruh politik dipelopori antara lain oleh W. Wilson dan Hegel, sedangkan yang sebaliknya dipelopori antara lain oleh Karl Marx, James Svara dan Goerge Edward II. Pandangan kelompok Wilson didasarkan birokrasi hanya sebagai pelaksana 
kebijakan yang tidak boleh mengambil kebijakan politik. Sedangkan kelompok lainnya mempertanyakan apakah birokrasi harus netral bila selalu dalam kehidupan politik? sehingga birokrasi harus memihak pada pihak dominan.

Sejauh ini definisi dan kerangka konseptual tentang netralitas ASN masih sangat dominan dikaitkan dengan aspek politik. Padahal jika mengacu kepada konsep dasar netralitas yaitu imparsialitas, maka cakupannya akan lebih luas.

\section{Netralitas Birokrasi}

Aparatur Sipil Negara merupakan suatu konsep yang tidak dapat dipisahkan dari konsep birokrasi khususnya mengenai netralitas birokrasi. Netralitas dalam administrasi negara atau pemerintahan sangat sulit diwujudkan. Netralitas yang baik memang tidak boleh memihak di antara pro dan kontra, akan tetapi netralitas memihak yang sesuai kebenaran dengan pertimbangan yang ilmiah dan suara hati nurani serta tanggung jawab yang sesuai dengan azas netralitas dan profesionalime.

Demokrasi dan Pilkada tidak seharusnya mereduksi atau menghilangkan makna keterlibatan aparatur birokrasi dalam agenda tersebut, tetapi lebih memberikan ruang serta menjamin keterlibatan aparatur birokrasi sebagai alat negara untuk mengotrol serta memberikan pendidikan politik ala negara terhadap masyarakat dalam konsolidasi demokrasi lokal maupun secara nasional. Dengan hal tersebut birokrasi yang bersifat kaku dan pasit dapat menjadi birokrasi yang netral aktif sebagai alat negara dalam mewujudkan demokrasi yang sehat dan damai.

Pilkada merupakan konsolidasi demokrasi di tingkal lokal, yang dimana dalam proses penyelenggaraanya selalu melahirkan konflik, tidak terkecuali proses keterlibatan aparatur sipil negara. Dalam teori birokrasi Weberian menempatkan aparatur sipil negara (birokrasi) sebagai personifikasi yang harus bebas dari kepentingan kelompok maupun golongan, dalam Undang-undang yang mengatur tentang aparatur sipil negara juga membahas antara relasi biorkrasi dengan politik, yang secara umum menenkankan aparatur birokrasi harus netral, serta bebas dari intervensi politik. (Sumaryana. 2005:135)

Dalam dimensi sebagai penyelenggaran publik aparatur birokrasi menempatkan diri sebagai penyelenggara publik dan sebagai penyelenggara politik. Hal inilah yang menjadi dasar bahwa aparatur sipil negara (birokrasi) harus diberikan ruang oleh negara untuk terlibat secara netral aktif dalam kegiatan politik, sebagai konseskuensinya adalah aparatur birokrasi mampu menjadi garda terdepan dalam merumuskan kebijakan, pelaksanakan kebijakan serta pengotralan kembali dari kebijakan politik tersebut. (Santoso, 2014: 4)

\section{Pemilihan Kepala Daerah (Pilkada)}

Pilkada merupakan salah satu kegiatan politik yang merupakan implementasi hak kedaulatan 
rakyat dalam memilih pemimpin untuk masa 5 tahun mendatang. Melalui Pilkada terjadi pergantian pemegang kekuasaan secara teratur, damai dan berkualitas. Menurut Peraturan Pemerintah Nomor 6 Tahun 2005 Tentang Pemilihan, Pengesahan, Pengangkatan dan Pemberhentian Kepala Daerah dan Wakil Kepala Daerah, Pemilihan kepala daerah adalah sarana pelaksana kedaulatan rakyat di wilayah propinsi dan/atau Kabupaten/Kota berdasarkan Pancasila dan UUD 1945 untuk memilih kepala daerah dan wakil kepala daerah.

\section{Metodologi Penelitian}

Penelitian ini menggunakan penelitian kualitatif dengan pendekatan deskriptif analisis, karena persoalannya sangat komprehensif, mendalam dan sangat luas. Pengumpulan data dilakukan dengan observasi, wawancara dan dokumentasi.

\section{Hasil Penelitian}

Netralitas menurut Undang-Undang Nomor 5 Tahun 2014 berarti setiap pegawai ASN tidak berpihak dari segala pengaruh manapun dan tidak memihak kepada kepentingan siapapun. Seorang ASN diharuskan untuk dapat bersikap netral dalam perhelatan pemilihan umum, sehingga bagi para pelanggar aturan netralitas akan diberikan sanksi yang sesuai dengan perbuatannya.

Komisi Aparatur Sipil Negara (KASN) selaku pihak yang bertanggung jawab dalam mengawasi pelaksanaan norma, dasar, kode etik, dan kode perilaku ASN, dalam melaksanakan pengawasannya tersebut berwenang memutuskan adanya pelanggaran-pelanggaran yang dilakukan oleh pegawai Aparatur Sipil Negara. KASN juga telah menjelaskan secara jelas terkait hal-hal yang tidak boleh dilakukan oleh ASN, diantaranya yaitu:

1. Kampanye atau sosialisasi melalui media sosial (posting, share, berkomentar, Foto bareng calon pasangan calon, Like status Facebook (pasangan calon);

2. Menghadiri deklarasi calon;

3. Ikut sebagai panitia atau pelaksana kampanye;

4. Ikut kampanye dengan atribut ASN;

5. Ikut kampanye dengan menggunakan fasilitas negara;

6. Menghadiri acara partai politik (parpol);

7. Menghadiri penyerahan dukungan parpol ke pasangan calon (paslon);

8. Mengadakan kegiatan mengarah keberpihakan (ajakan, himbauan, seruan, pemberian barang);

9. Memberikan dukungan ke calon legislatif/calon independen kepala daerah dengan memberikan KTP;

10. Mencalonkan diri dengan tanpa mengundurkan diri (sebagai ASN);

11. Membuat keputusan yang menguntungkan atau merugikan paslon; 
12. Menjadi anggota atau pengurus parpol;

13. Mengerahkan ASN untuk ikut kampanye;

14. Pendekatan ke parpol terkait pencalonan dirinya atau orang lain;

15. Menjadi pembicara/narasumber dalam acara parpol;

16. Foto bersama paslon dengan mengikuti simbol tangan atau gerakan yang digunakan sebagai bentuk keberpihakan. Dari poin-poin di atas, larangan yang dilakukan oleh

Dalam surat edaran Menteri Pendayagunaan Aparatur Sipil Negara dan Reformasi Birokrasi diperjelas kembali bahwa salah satu larangan netralitas ASN adalah seorang ASN wajib menghindari konflik kepentingan pribadi, kelompok ataupun golongan, dalam artian ASN dilarang melakukan kegiatan yang mengarah kepada keberpihakan terhadap salah satu pasangan calon dalam pemilihan umum.

Berdasarkan hasil penelitianadapun daftar pelanggaran netralitas ASN di Kabupaten Bener Meriah pada tahun 2017 antara lain:

1. Terlibat dalam kampanye dan sosialisasi melalui media sosial (melanggar poin 1 pedoman KASN),

2. Menghadiri deklarasi pasangan calon (melanggar poin 2 pedoman KASN),

3. Melakukan foto bersama calon/paslon dengan mengikuti simbol gerakan tangan/gerakan yang mengindikasikan keberpihakan (melanggar poin 16 pedoman KASN),

4. Mengadakan kegiatan yang mengarah kepada keberpihakan (pertemuan, ajakan, himbauan, seruan, dan pemberian barang)(melanggar poin 8 pedoman KASN),

5. Menjadi peserta kampanye dengan memakai atribut partai/atribut ASN (melanggar poin 5 pedoman KASN),

6. Terlibat dalan kegiatan kampanye (melanggar poin 3 pedoman KASN).

Secara teoritis penyebab ketidaknetralan ASN bersumber dari berbagai macam penyebab. Pada penelitian ini peneliti menggunakan indikator implementasi kebijakan menurut Van Horn dan Van Meter untuk membahas permasalahan implementasi Undang-Undang Nomor 5 Tahun 2014 Tentang Aparatur Sipil Negara khususnya mengenai netralitas ASN di Kabupaten Bener Meriah pada pemilihan kepala daerah tahun 2017. Adapun indikator yang sesuai dengan permasalahan peneliti dan ditemukan kesesuaian antara lain indikator komunikasi, indikator sumber daya, indikator disposisi, indikator struktur birokrasi, dan indikator lingkungan ekonomi, sosial dan politik.

Van Meter dan van Horn mengatakan bahwa tujuan dari implementasi kebijakan harus dipahami oleh pelaksana dan sasaran kebijakan. Oleh karena itu, tujuan dan sasaran dari sebuah kebijakan harus terlebih dahulu dikomunikasikan. Hal ini sejalan dengan pendapat Edward III yang menyatakan bahwa dalam suatu implementasi kebijakan diperlukan adanya transmisi atau penyaluran komunikasi dimana sebelum seseorang menerapkan suatu keputusan maka mereka harus sudah siap dan mengerti terhadap keputusan yang sudah diambil untuk dapat diimplementasikan. 
Berdasarkan hasil penelitian diketahui bahwa komunikasi yang dilakukan para stakeholder yang memiliki wewenang untuk menjaga netralitas ASN sesuai dengan UU ASN yaitu BKPP, Kesbangpol dan Panwaslih Kabupaten Bener Meriah adalah dengan cara memberikan sosialisasi melalui penyampaian informasi berupa penjabaran mengenai aturan-aturan netralitas ASN pada ranah politik, serta sanksi-sanksi yang akan diberikan jika para ASN melanggarnya, namun diketahui penyampaian informasi belum mampu menahan para ASN untuk tidak melakukan pelanggaran netralitas ASN tersebut pada pemilihan kepala daerah tahun 2017 karena para ASN masih terpengaruh oleh janji-janji politik yang diberikan para pasangan calon.

Sosialisasi dilakukan sebelum masa pemilihan kepala daerah dan selama masa pemilihan kepala daerah berlangsung yang diantaranya berkaitan dengan regulasi dan pengawasan partisipatif kepada para ASN. Tujuan umum kegiatan tersebut diantaranya membatasi hak-hak ASN sesuai dengan UU ASN yang berlaku khususnya dalam membatasi hak demokrasinya sebagai warga negara, karena bagaimanapun para ASN juga akan melakukan pemilihan kepala daerah, namun sebagai aparatur negara ada netralitas dalam birokrasi yang harus mereka jaga. Pada indikator komunikasi diketahui masih belum maksimal dilakukan kepada para ASN karena masih terdapat pelanggaran dan membuktikan bahwa ke 21 orang ASN masih abai terhadap ketentuan yang telah ada pada UU ASN.

Sumber daya merupakan indikator yang tidak dapat terpisahkan dalam pelaksanaan sebuah kebijakan. Sumber daya menurut Van Horn dan Van Meter menyangkut dengan ketersediaan dana atau sumber daya finansial dalam penerapan sebuah kebijakan. Penelitian yang peneliti lakukan tentang Netralitas Aparatur Sipil Negara Dalam Pemilihan Kepala Daerah Di Kabupaten Bener Meriah tidak ditemukan permasalahan yang sesuai dengan indikator sumber daya, sehingga pada hasil penelitian sebagaimana telah disampaikan bahwa peneliti tidak melakukan pencarian dan pengumpulan data terhadap indikator sumber daya.

Sebagaimana diketahui disposisi merupakan sikap, watak ataupun perilaku para pelaksana kebijakan. Berdasarkan hasil penelitian diketahui bahwa disposisi atau watak pelaksana dapat terbagi menjadi 2 yaitu watak pelaksana yang didalamnya adalah pihak BKPP, Panwaslih dan Kesbangpol sebagai instansi-instansi pemerintah yang bertugas menyampaikan Undang-Undang ASN kepada para ASN agar dapat diimplementasikan secara maksimal, serta 1 lagi merupakan watak para ASN itu sendiri.

Watak para pelaksana kebijakan diketahui masih belum memiliki komtimen yang kuat dalam menjalankan amanah UU ASN karena dalam memberikan sanksi kepada 21 orang ASN yang melanggar netralitas hanya sekedar memberikan teguran lisan saja, tidak ditindaklankjuti sebagaimana ketentuan dalam UU ASN dan PP Kedisiplinan ASN. Sedangkan watak/perilaku ASN yang melanggar jelas terlihat bahwa mereka tidak menerapkan profesionalisme dan komitmennya sebagai ASN.

Pada indikator disposisi, perilaku atau watak pelaksana yang baik, berkomitmen yang teguh, 
merupakan sebuah keharusan karena sebaik apapun penyampaian perintah guna menjaga netralitas yang disampaikan oleh seorang pemimpin dianggap angin lalu oleh para bawahannya jika perilaku pemimpinnya masih belum netral. Oleh karenanya, penting bagi para pemimpin untuk selalu menjaga perilakunya dalam menggunakan hak politiknya yang sudah dibatasi. Untuk memperkecil gap (jurang), pemimpin harus berusaha menciptakan suasana saling percaya-mempercayai sebagai kondisi yang baik untuk berkomunikasi, apabila sebelumnya sudah beranggapan berarti akan memperlemah komunikasi (Terry, 2016: 145).

Hal inilah salah satunya yang menyebabkan para ASN yang melakukan pelanggaran netralitas pada masa pemilihan kepala daerah di Kabupaten Bener Meriah pada tahun 2017 tidak diberikan sanksi yang sesuai dengan ketentuan UU ASN dan PP Kedisiplinan ASN karena para pelaksana dalam tingkatan makro (stakeholder) yang tidak tegas dan berkomitmen teguh dalam menerapkan kebijakan.

Dalam tingkatan mikro yaitu para ASN juga masih memiliki prilaku tidak profesional yang disebabkan:

1. Mindset pegawai ASN yang cenderung berpihak pada atasan yang diwariskan oleh birokrasi politik pada era pemerintahan orde baru. Banyak ASN tidak memahami prinsipprinsip netralitas dan tidak menyadari bahwa apa yang mereka lakukan melanggar ketentuan yang berlaku.

2. Kesadaran pegawai ASN yang masih rendah akan pentingnya bersikap netral dalam menyelenggarakan pemerintahanan, pembangunan, dan pelayanan publik serta menganggap keberpihakan merupakan sesuatu yang lumrah.

3. Sikap sebagian pegawai ASN yang lebih mengutamakan cara mudah dalam mencapai karier yang lebih tinggi dengan menunjukkan loyalitas kepada atasan dari pada menunjukkan profesionalitas dan kinerja.

Persoalan netralitas merupakan persoalan kompleks. Diperlukan koordinasi yang intens dan membutuhkan waktu ketika pelanggaran netralitas terjadi. Jalur pelaporan, pembuktian, dan penindakan terkadang dianggap lebih merepotkan dan beresiko, sehingga dianggap lebih aman dengan tidak melaporkannya. Para birokrat karena alasan prioritas terkadang menghindari koordinasi dengan badan-badan lain. Padahal, penyebaran wewenang dan sumber-sumber untuk melaksanakan kebijakan-kebijakan yang kompleks membutuhkan koordinasi (Winarno, 2014 : 209).

Pada indikator struktur birokrasi diketahui ada dua aspek yang menjadi karakteristiknya yaitu ketersediaan Standar Operasional Prosedur (SOP) dan Fragmentasi.

Dalam hal netralitas ASN yang menjadi SOP sampai saat ini hanya masih Undang-Undang Nomor 5 Tahun 2014 tentang Aparatur Sipil Negara dan Peraturan Pemerintah Nomor 53 Tahun 2010 tentang Disiplin Pegawai Negeri Sipil. Serta yang menjadi fragmentasi adalah Adapun pihak-pihak yang terlibat dalam penerapan Undang-Undang ASN khususnya mengenai netralitas ASN pada masa Pilkada tahun 2017 di Kabupaten Bener Meriah adalah BKPP, Kesbangpol dan Panwaslih. 
Lingkungan ekonomi, sosial dan politik memberi pengaruh paling signifikan dalam permasalahan netralitas ASN pada pemilihan kepala daerah di Kabupaten Bener Meriah pada tahun 2017. Berdasarkan hasil penelitian diketahui 21 orang ASN yang melakukan pelanggaran netralitas disebabkan oleh dau penyebab yaitu penyebab kekerabatan (hubungan primordial), dan penyebab motivasi mendapatkan jabatan atau promosi jabatan yang dijanjikan oleh para pasangan calon.

Pada penyebab primordial, Ikatan-ikatan primordial dalam masyarakat Indonesia masih sangat kental. Hal ini sangat berpengaruh dalam penentuan sikap politik seorang ASN. Jika ASN memiliki saudara, kerabat atau keluarga yang dituakan terlibat dalam politik praktis dalam kehidupan sosial sudah pasti mereka tidak akan membiarkan kerabatnya berjuang sendiri dalam mencapai tujuan.

ASN berada dalam posisi yang dilematis oleh kepentingan politik. Di satu sisi, mereka adalah pegawai yang diangkat, ditempatkan, dan dipindahkan dan diberhentikan oleh pejabat pembina kepegawaian (PPK). Kondisi seperti ini membuat saling berkaitan. Di sisi lain, ASN harus netral untuk menjaga profesionalismenya dalam menjalankan tata kelola pemerintahan dan pelayanan publik. Sebagai pelaksana kebijakan dan pemegang kekuasaan dan kewenangan dalam pengelolaan anggaran dan sumberdaya di dalam birokrasi, ASN sangat dimungkinkan dijadikan alat bagi pejabat politik untuk dapat mempertahankan/mendapatkan kewenangan dan kekuasaannya. Netralitas merupakan asas yang penting dalam penyelenggaraan tugas dan pelayanan publik, tugas pemerintahan dan tugas pembangunan.

Berdasarkan hasil penelitian diketahui bahwa tindak lanjut punishment bagi para ASN yang melakukan pelanggaran netralitas adalah hanya dengan diberikannya teguran secara lisan kepada 21 orang ASN tersebut dan tidak dilanjutkan dengan pemberian punishmentsebagaimana yang diatur dalam UU ASN dan PP Kedisiplinan ASN.

Sebenarnya keenam pelanggaran yang dilakukan oleh 21 orang ASN di Kabupaten Bener Meriah pada pemilihan kepala daerah pada tahun 2017 dapat diberikan sanksi berdasarkan jenjang kesalahannya, namun ke 21 orang tersebut semuanya hanya diberikan sanksi ringan yaitu teguran secara lisan saja. Seharusnya dapat dijatuhkan hukuman disiplin oleh pejabat yang berwenang menghukum dilaksanakan sesuai dengan tata cara yang telah diatur dalam Peraturan Pemerintah Nomor: 53 tentang Disiplin ASN dan Peraturan Kepala Badan Kepegawaian Negara Nomor: 21 Tahun 2010 tentang Ketentuan Pelaksanaan Peraturan Pemerintah Nomor: 53 Tahun 2010 tentang Disiplin ASN.

\section{Kesimpulan}

Berdasarkan temuan penelitian dan uraian hasil tersebut, adapun kesimpulan peneliti terhadap hasil penelitian ini adalah sebagai berikut: 
1. Pada tahun 2017 dilakukan pemilihan kepala daerah di Kabupaten Bener Meriah dan ditemukan 21 orang ASN melakukan pelanggaran netralitas.

2. Faktor-faktor yang menyebabkan ASN melakukan pelanggaran netralitas dalam penelitian ini dianalisis menggunakan indikator implementasi menurut Van Horn dan Van Meter, yaitu:

a. Komunikasi

komunikasi yang dilakukan para stakeholder yang memiliki wewenang untuk menjaga netralitas ASN sesuai dengan UU ASN yaitu BKPP, Kesbangpol dan Panwaslih Kabupaten Bener Meriah adalah dengan cara memberikan sosialisasi melalui penyampaian informasi berupa penjabaran mengenai aturan-aturan netralitas ASN pada ranah politik, serta sanksisanksi yang akan diberikan jika para ASN melanggarnya, namun diketahui penyampaian informasi belum mampu menahan para ASN untuk tidak melakukan pelanggaran netralitas ASN tersebut pada pemilihan kepala daerah tahun 2017.

b. Sumber daya

Tidak ditemukan permasalahan yang sesuai dengan indikator sumber daya.

c. Disposisi

Watak para pelaksana kebijakan diketahui masih belum memiliki komtimen yang kuat dalam menjalankan amanah UU ASN karena dalam memberikan sanksi kepada 21 orang ASN yang melanggar netralitas hanya sekedar memberikan teguran lisan saja, tidak ditindaklankjuti sebagaimana ketentuan dalam UU ASN dan PP Kedisiplinan ASN. Sedangkan watak/perilaku ASN yang melanggar jelas terlihat bahwa mereka tidak menerapkan profesionalisme dan komitmennya sebagai ASN.

d. Struktur Birokrasi

Dalam hal netralitas ASN yang menjadi SOP sampai saat ini hanya masih Undang-Undang Nomor 5 Tahun 2014 tentang Aparatur Sipil Negara dan Peraturan Pemerintah Nomor 53 Tahun 2010 tentang Disiplin Pegawai Negeri Sipil. Serta yang menjadi fragmentasi adalah pihak-pihak yang terlibat dalam penerapan Undang-Undang ASN khususnya mengenai netralitas ASN pada masa Pilkada tahun 2017 di Kabupaten Bener Meriah adalah BKPP, Kesbangpol dan Panwaslih.

e. Lingkungan Ekonomi, Sosial dan Politik

Lingkungan ekonomi, sosial dan politik memberi pengaruh paling signifikan dalam permasalahan netralitas ASN pada pemilihan kepala daerah di Kabupaten Bener Meriah pada tahun 2017. Berdasarkan hasil penelitian diketahui 21 orang ASN yang melakukan pelanggaran netralitas disebabkan oleh dau faktor yaitu faktor kekerabatan (hubungan primordial), dan faktor motivasi mendapatkan jabatan atau promosi jabatan yang dijanjikan oleh para pasangan calon. 
3. Tindak lanjut punishment bagi para ASN yang melakukan pelanggaran netralitas adalah hanya dengan diberikannya teguran secara lisan kepada 21 orang ASN tersebut, dan tidak dilanjutkan dengan pemberian punishment sebagaimana yang diatur dalam UU ASN dan PP Kedisiplinan ASN.

\section{Daftar Pustaka}

Agustino, Leo. 2008. Dasar-dasar Kebijakan Publik. Bandung: Alfabeta.

Nugroho, Riant. 2003 Kebijakan Publik Formulasi, Implementasi Dan Evaluasi. Jakarta: PT. Elex Media Komputindo.

Usman, Nurdin. 2004. Konteks Implementasi Berbasis Kurikulum. Yogyakarta: Bintang Pustaka.

Agustina, Hartini. 2002. Analisis Hubungan Antara Komitmen Karyawan, Iklim Organisasi dan Performansi Kerja Karyawan,Studi Kasus Unit Corporate \& Divisi Network PT Telkom Indonesia, Tbk, JREM.

Syaukani, dkk. 2004. Otonomi Daerah Dalam Negara Kesatuan, Yogyakarta: Pustaka Pelajar.

Dahl, Robert A. 1992. Demokrasi dan Para Pengkritiknya. Jakarta: PT. Yayasan Obor Indonesia.

Sumaryana, Asep. 2005. Birokrasi Dan Pelayanan Publik. Jurnal Administrasi Publik.

Terry, George R. 2016. Dasar-Dasar Manajemen. Alih Bahasa: G.A. Ticoalu. Jakarta: Bumi Aksara.

Peraturan Pemerintah Nomor 100 Tahun 2000 Tentang Pengangkatan Pegawai Negeri Sipil Dalam Jabatan Struktural.

Peraturan Pemerintah Nomor 53 Tentang Disiplin Pegawai Negeri Sipil.

Peraturan Pemerintah Nomor 6 Tahun 2005 Tentang Pemilihan, Pengesahan, Pengangkatan dan Pemberhentian Kepala Daerah dan Wakil Kepala Daerah

Undang-Undang Nomor 32 Tahun 2004 Tentang Pemerintahan Daerah

Undang-undang Nomor 43 Tahun 1999 tentang Perubahan atas Undang-undang Nomor 8 Tahun 1974 tentang Pokok-Pokok Kepegawaian.

Undang-Undang Nomor 5 Tahun 2014 Tentang Aparatur Sipil 